\title{
ONOMÁVEIN
}

Journal of linguistics, philology and translation

\section{An integrated approach to the higher education terminology in Spanish-Russian university texts}

\author{
Oksana Polyakova \\ Universidad Católica de Valencia San Vicente Mártir \\ España
}

\section{(c) $($ i) $\ominus$}

Oksana Polyakova: Instituto de Lenguas, Universidad Católica de Valencia San Vicente Mártir, España. | E-mail: oksana.polyakova@ucv.es 


\section{Abstract}

The commitment of European and non-European countries for the convergence of educational standards happened decades ago. In the beginning, in 1999 (Bologna Declaration) Spain became an integral part of the Bologna Process. Meanwhile the Russian Federation required four more years to respond to this initiative and sign in 2003 the Berlin Communique. Many issues were raised by the alignment of different education systems and their adaptation to common quality standards. However, few solutions were offered to tackle terminology issues in university domain.

In this study, we will focus on how we can overcome higher education terminology differences. We will analyse Spanish-Russian university texts, exploit a mixed monolingual and bilingual corpus as well as investigate the system for terminological equivalence of terms. Finally, we will elaborate a bilingual glossary of terms, synonyms and abbreviations conceivably to meet the needs of intercultural mediators, translators or education experts.

Keywords: terminology; translation; equivalence; corpus linguistics; higher education; European Higher Education Area. 


\section{Introduction}

The overall European idea is a cultural connection which is an integral element of the educational partnership. Keeping up with new higher education challenges, a continuous collaboration of the European Union members opens new ways of interaction among them and their closest continental neighbours. Accordingly, European issues as a set of cultural and educational connections have gained popularity in the context of the new partnership called the Bologna Process (Sorbonne Joint Declaration 1998) and, later, the European Higher Educational Area (EHEA). Therefore, this setting is of vital importance for higher education cooperation between Spain and Russia.

The present corpus-based study aims at analysing characteristics of the academic terminology through Spanish and Russian translation research considering the following complementary objectives:

- analyse professional and academic documentation structure of university texts,

- study selected higher education domains and translations (Spanish-Russian) to establish equivalences or find solutions for cases of equivalence absence,

- develop a lexicographical product of professional and educational use.

It should be clarified that the time (the fundamental period for the EHEA documentation compiled from 1998 to 2012) and geographical limits (Spain and the Russian Federation) affect the results of this study. Under these objectives, translations in the field of European tertiary education should be studied in the following manner.

This paper first offers a brief review of the theoretical background of terminology, translation, specialised languages and lexicography. Then, it addresses corpus linguistics as the primary methodological approach. Started in documentary phase, corpus methodology develops effective schemes of collecting original data in Spanish and Russian for its further distribution by thematic subdivisions. Finally, the study delivers verifiable results through a bilingual lexicographical product.

\subsection{Terminology}

The starting point for this research is the terminology. We will focus on its three main perspectives suggested by Sager (1993: 22) and Alcaraz Varó \& Martínez Linares (1997: 563): a terminology is a scientific field that offers theoretical foundations of further applied research (1), terminology is an empirical approach towards a compilation of terms (2) and terminology is a range of specific subject-related terms (3). We will use the same mechanics to advance work.

Initially, guiding principles of terminology (1) have evolved gradually over the last decades and reached national and international recognition, advises Cabré (1993: 21). On its way, vari- 
ous theories have generated essential improvements such as traditional theories established specific standards and identified terms as an isolated item (Wüster, 1967), sociocommunicative theory (Gaudin, 1993) and communicative theory of terminology (Cabré, 1993) reaffirmed communicative values of terms inseparable from professional domains. Meanwhile, the sociocognitive theory is focused on interconnection patterns of terms within a specialised language (Temmerman, 1997), modern theories of frames create ontologies (Faber et al., 2006) or tend to deal with terminology dynamics inside of each specialised fields (Faber Benítez \& León Araúz, 2010). For this research, we choose the scope of the communicative theory of terminology because of its contextual value and a close connection to any professional domain.

As we have mentioned above, the next point of terminological background (2) of this study is a practical focus on terms compilation. To achieve adequate information treatment, we have decided to apply corpus methodology that will be detailed in the second part of the present document.

With regards to the last perspective on terminology as a list of specific terms (3), our focus is placed on higher education terminology represented through a specialised bilingual glossary in the fourth part of the paper.

\subsection{Translation}

The next part of the theoretical background, as set out above, is the translation. Current understanding of translation as a skill, know-how or even a process of solving problems related to each translation (Hurtado Albir, 2011) fully reflects its primary purpose. Furthermore, García Yebra (1989) highlights two phases of the translation process: understanding the original text and then expressing it through another language. However, the debate continues how to transmit an equivalent message.

Much of the literature on translation studies pays particular attention to the complex concept of translation equivalence. In an investigation into translation equivalence, Panou (2013) claims it to be the focal point of translation difficulties. It is worth mentioning that the old debate on equivalence in difference (Jakobson, 1959), formal and dynamic or functional equivalence (Nida, 1964; Nida \& Taber, 1982), and cultural equivalence or cultural substitution (Newmark, 1988; Baker, 1992) types are of high relevance for the present study.

Jakobson's study of linguistic aspects of translation is made up of three types of equivalence regarding difference: intralingual or rewording, interlingual or translation proper and intersemiotic or transmutation. The first one relates to the same language, the second is between two languages and the last one includes nonverbal sign systems respectively. Jakobson (1959) argues that translation of signs is of vital importance for a translation process. His studies, based on a careful language comparison, demonstrated equivalence in difference, point out adequate transference of grammar and lexical differences of source and target languages. 
By drawing upon the concept of formal equivalence, Nida initially defended fidelity to the source in terms of lexical details. However, later he contrasted it with the dynamic equivalence. So, his focus on dynamic or functional equivalence was closer to the culture of the target language. The definition of translation introduced by Nida and Taber (1982: 208), as "the reproduction in a receptor language of the closest natural equivalent of the source language message, first in terms of meaning, and second in terms of style", aligns functional equivalence with the target culture.

A broader cultural perspective was adopted by Newmark (1988), who recognised the necessity of cultural equivalence or "an approximate translation" (ibid., 1988: 82) to preserve the pragmatic value of translation. Moreover, Baker (1992: 31) suggested a specific strategy to achieve a familiar concept arising from a translated text by "replacing a culture-specific item or expression with a target-language item to have a similar impact on the target reader".

In conclusion, translation equivalence as outlined in the previous studies shows a functional approach towards a search for the accurate culturally sensitive transfer of the original meaning. By introducing Vinay and Darbelnet (2000) and Latyšev and Semenov's (2003) techniques, we provide the reader with practical methods that will let us quantify EHEA bilingual translations.

On the one hand, Vinay and Darbelnet (2000: 84-93) trace the development of translation techniques aimed at offering practical solutions to translators such as: (a) borrowing, a direct transfer of a word from the source language (SL) into the target language (TL); (b) calque, a variation of the borrowing when an SL expression is adapted employing the TL; (c) literal translation, a reproduction of an original SL expression using the TL; (d) transposition, a partial substitution of the original SL expression; (e) modulation, a necessity to change also the semantic structure of the TL; (f) equivalence, a description of an SL situation with different structural and stylistic means of the TL; (g) adaptation, an SL reference change in the absence of a similar situation in the TL.

On the other hand, Latyšev and Semenov (2003) note that some of the major contradictions between the original text and how its translations appear in translations. The authors assign synonymic values to both terms: equivalent translation and the optimum translation. In the case of equivalence absence, the next techniques are intended to solve the problem (ibid., 2003: 129-132): (1) transliteration or rewriting of the SL word using TL letters, (2) calque or substituting parts of SL inequivalent word by their direct equivalents, (3) descriptive translation or describing of the original lexical unit by means of the TL and (4) approximate translation or searching for the closest concept existing in the TL to transfer the meaning of the original SL concept.

Following the above, our research is intended to detect equivalence models in the Spanish and Russian educational context. The translation process is a practical culturally conditioned procedure of transforming the $S L$ message into the $T L$ one. In the same vein and following our 
research objectives, we are going to apply a reduced number of techniques that combine the approaches of Vinay \& Darbelnet (2000) and Latyšev \& Semenov (2003), such as:

1. equivalence is a description of an $\mathrm{SL}$ situation with different structural and stylistic means of the $T L$,

2. calque allows replacing originally specialised lexis for a similar word or expression accepted in the $T L$,

3. transliteration offers the way to write the original word using letters of TL,

4. descriptive translation addresses the absence of a parallel translation of the TL by explaining the original expression,

5. approximate translation requires a mastery of specialised language to suggest a translated denomination akin to the original concept, so, it is generally used in the most demanding cases.

Nevertheless, it should be pointed out that both working languages are rooted in a common Indo-European language family (Hualde et al., 2010). In the opinion of Aznar Royo and Alarcón Rodríguez (2006: 9), this common basis makes it easier to cope with such differences as the analytical structure of Spanish that relies heavily on prepositions versus the synthetical structure of Russian language that uses word endings to express grammar functions.

Despite lexical, morphological, phonetic and syntactic peculiarities of each language, we still consider linguistic fieldwork which will help deepen the knowledge of translation challenges. Synonyms and abbreviations are among the special features that we want to add to the undertaken equivalence research. When referring to synonymy in translation, Newmark (1988: 84) puts it like "a near TL equivalent to an SL word in a context, where a precise equivalent may or may not exist". This definition will help identify such cases during the study. Since abbreviation is another notable phenomenon, defined as a shortening or reduction of a linguistic unit based on principles of the linguistic economy (Alcaraz Varó \& Martínez Linares, 1997: 3), during the research, we will detect abbreviations too.

It is worth considering translation equivalence to be a critical turning point of the research whereas we have to bear in mind the interdisciplinary value of the present study.

\subsection{Specialised languages}

In the upcoming section, we will focus on specialised languages in the linguistic environment. Crystal (2008: 444) highlights the fact that human language "is highly specialised, as the behavioural consequences of using a linguistic signal are less predictable”. Moreover, Swales (1990, 2004), Bhatia (1993) and Lerat (1997) consider the consistency of communicative purposes and discourse configuration in terms of situated linguistic behaviour. Another relevant issue raised by Sager et al. (1980) is the importance of comprehensiveness of special languages. 
According to the functional approach suggested by Bahtin (1996), speech genres are also closely related to professional activities. So, the notion of professional language is connected to professional communication; meanwhile, academic language is located in the university and used for training or research (Alcaraz Varó \& Hughes, 2002).

Furthermore, a classification of the university academic language applied to this research becomes a part of subsequent empirical work and will be supported by the document organisation within the future linguistic corpus. In line with this, textual typologies of English, Spanish or Russian academic, legal and administrative language suggested by Varela Fernández (2002), Verba and Guzmán Tirado (2005) and Sanz Álava (2007) highlight the importance of its organisation.

Different academic language samples in Spanish and Russian were also analysed by Polyakova and Candel-Mora (2016) and their proposal of academic language classification determines three groups: academic and administrative, specialised university texts and legal texts. The first group of academic and administrative texts comprises general administrative correspondence (e.g. letters, reports, certificates) as well as oral discourse (e.g. presentations). The second group of specialised university texts variety is divided into institutional texts (e.g. project, proposal) and properly specialised texts (e.g. specialised language of a specific area). The third group of legal texts lists institutional agreements (e.g. contracts, agreements) and academic certification (e.g. official diploma, qualifications, academic certificates).

Therefore, the above-mentioned specialised documentation typology is the cornerstone on which the research is settled. Academic language classification sets the scheme for the next methodological steps such as linguistic corpus compilation and further analysis of Spanish-Russian translations.

\subsection{Bilingual lexicography}

The work of the translator relies heavily on specialised information available in dictionaries, vocabularies or glossaries. It is one of the main reasons why lexicography as a process of compilation of a dictionary has acquired relevance for modern translation professionals. Even though the term 'lexicography' denotes both the scientific technique of composing dictionaries and glossaries and a linguistic discipline that provides both theoretical and methodological foundations of lexicographical practice (Alcaraz Varó \& Martínez Linares, 1997: 328), the emphasis is placed on its empirical value for the current research.

There appears to be quite a special connection with translation due to its specific needs according to Newmark (1988), Hannay (2003) and Tarp (2009) as professional translators frequently use monolingual and bilingual dictionaries. Conclusions drawn by Calvo Rigual and Calvi (2014: 47) on lexicography and translators' needs suggest the necessity of further research because "the picture is still not clear". 
In words of Bergenholtz and Tarp (2010: 27), "the focus of preparing dictionaries for a particular subject-field should be the needs of its user group in specific situations". Precisely this opinion encourages us to proceed with the design of a lexicographical product for education experts, mediators and translators.

\section{Methodology}

To start with, Spanish-Russian academic study of the European Higher Education Area translations involves a detailed notion of its documentation structure. Accordingly, in addition to the specialised language classification, the project requires a solution built on a corpus approach. From the methodological point of view, the use of corpus provides further support for the correct organisation and compilation of translations.

Since corpus linguistics is considered an applied research tool (O'Keeffe \& McCarthy, 2010; McEnery \& Hardie, 2012), general and specific corpus design criteria suggested by various authors (Pérez Hernández, 2002; Vargas Sierra, 2005, 2006; Jiménez-Crespo, 2009; Villayandre Llamazares, 2010) are considered necessary for the present study. Among the general corpus criteria, we have chosen the following six:

- the purpose criterion is important because it makes us select official higher education documents both in Spanish and in Russian,

- the composition criterion is relevant because the academic language classification already described creates a transparent structural background for the corpus compilation,

- the data reliability criterion makes us collect only original Spanish or Russian texts for monolingual corpus parts along with official English-Spanish and English-Russian translations,

- compilation format criterion is a procedural condition because of which all corpus documents are saved as doc or pdffiles,

- representativeness criterion is meaningful because it ensures an adequate amount of specialised academic texts,

- corpus size criterion is essential too as it safeguards corpus representativeness.

Additionally, four specific corpus criteria such as quality (original texts, real-life contexts), quantity (maximum number of words possible), simplicity (automatic tools and human revision, txt format for future data analysis) and documents control (common data record with detailed information on files origin and type) were considered in this research.

Following corpus criteria and guidelines applied to specialised language classification, an overall amount of 116 files (61 Spanish, 55 Russian) were collected. Consequently, our corpus 
structure is linked to the documentation classification made earlier and includes the following parts: academic and administrative general corpus (AAG), specialised university texts corpus (SUT) and legal texts corpus (LT). The following table shows the percentage of the extracted information and demonstrates the numerical dominance of the Spanish language lexicon.

\section{TABLE 1}

Quantities of specialised lexis and files of each corpus

\begin{tabular}{lcccc}
\hline \multicolumn{2}{c}{ CORPUS } & \multicolumn{2}{c}{ WILES: } \\
\hline & SPANISH & RUSSIAN & SPANISH & RUSSIAN \\
\hline AAG monolingual & $90 \%$ & $10 \%$ & 19 & 17 \\
\hline SUT monolingual & $78 \%$ & $22 \%$ & 10 & 8 \\
\hline LT monolingual & $69 \%$ & $31 \%$ & 25 & 23 \\
\hline LT bilingual & $67 \%$ & $33 \%$ & 7 & 7 \\
\hline
\end{tabular}

The values listed in Table 1 show the necessity for a comprehensive and systematic approach towards Spanish-Russian translations study not only because of unequal educational structure but due to some language structure differences. Given the slightly unequal quantity of files in monolingual corpus parts, it is surprising to discover an overwhelming predominance of Spanish words even in bilingual files.

As a result, the following corpus was collected:

Corpus components: written texts

Encoding and annotation: simple, txt format

Elements' specificity: specialised elements included

Temporality: synchronous (2000-2012)

Purpose: specific purpose (training and study)

Language: monolingual Spanish, monolingual Russian, bilingual aligned corpus of official Spanish-Russian translations (all corpus parts were collected by us)

Words quantity: 2127457 words

Text distribution: balanced

Accessibility: private

Documentation: documented

Once the documents of the present corpus are selected, classified and saved as txt files, the second stage of specialised lexis extraction begins. Monolingual Spanish documents are processed through the Synchroterm software and we receive a long wordlist of glossary candidates. After that, we manually eliminate generally used words and expressions, leaving only 
the most frequent and relevant specialised ones. Regarding the monolingual Russian corpus, we were unable to use the Synchroterm tool because it failed to analyse the Cyrillic alphabet and the whole process had to be performed manually. There is no parallel bilingual Spanish-Russian corpus of EHEA declarations translated from English available; so, it was an extra difficulty detected during the research process. We created an aligned bilingual corpus, based on official translation sources, and again manually extracted parallel bilingual terms.

The next step was the creation of an Access database that offers the key advantage of saving all available data that was transformable into a complex or simple glossary.

\section{FIGURE 1}

Database item example

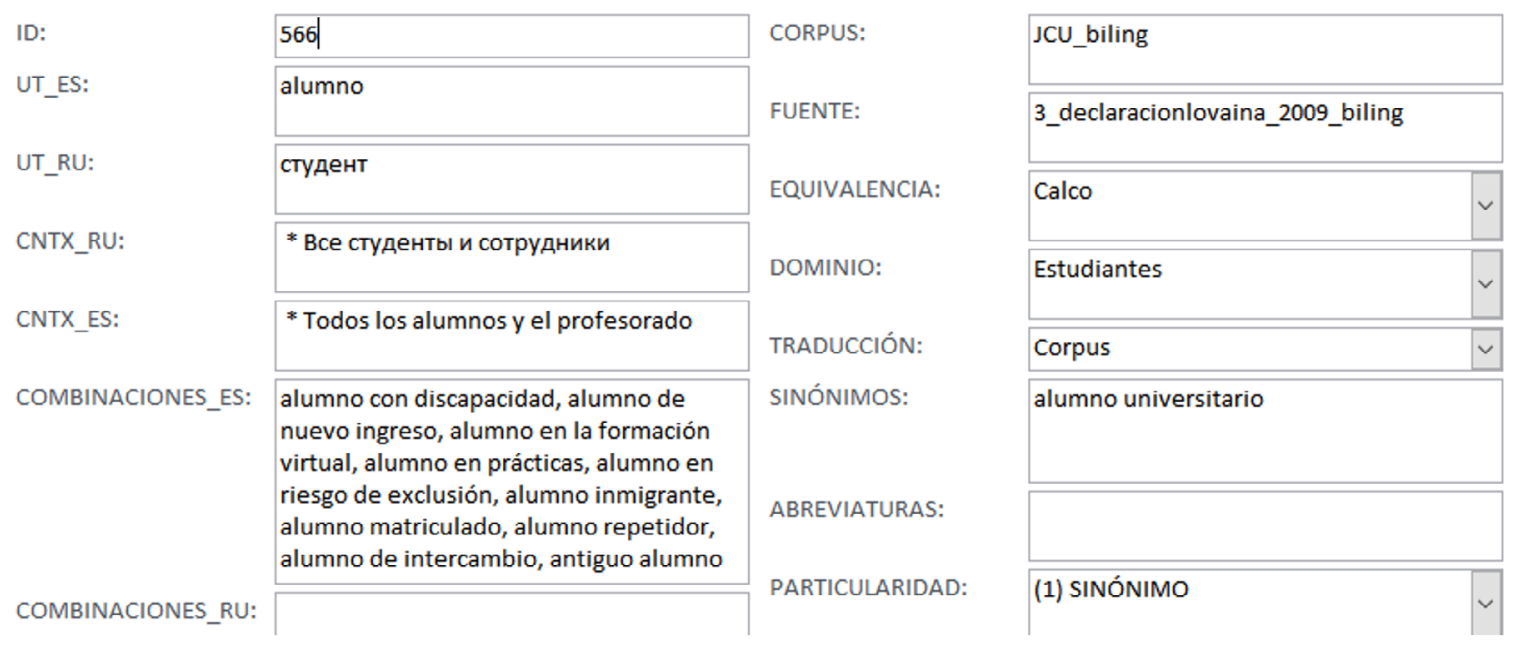

After creating the database, such notions as ID number, Spanish and Russian translations, context, collocations, information sources, translation equivalence, synonyms or abbreviations, domain or group are included (see Figure 1 above).

Thereafter, in order to facilitate a better conceptual distribution, the terms collected were included in one of ten groups ranging from Students to Society:

1. Students, 2. Examinations, certificates and diplomas, 3. Institutions and educational facilities, 4. Legislation, 5. Advisory bodies, 6. Managing staff, 7. Training processes and resources, 8 . Teaching staff, 9 . Systems and levels of education, 10. Society.

During this stage, a significant volume of translation data was gathered and handled enabling accurate and planned information management. At the end of the data processing, we applied a transparent methodological approach that allows classify and analyse academic terminology in the following way. 


\section{Data analysis}

The standard higher education platform, based on the Bologna Process, has allowed us to approach Spanish and Russian educational systems from their actual terminology and specialised lexis. During the initial phases of the empirical research, we collected monolingual and bilingual corpus containing 116 original documents (2 127457 words) and extracted academic lexis. As a result thereof, a database of 700 bilingual translation units was created and converted into a Spanish-Russian glossary. Next, we describe study results according to the conceptual groups' order. Special attention will be paid to the cases of equivalence or synonyms or abbreviations availability.

\subsection{Students}

The first group called Students contains 10 bilingual translations units, $80 \%$ of which are based on calque equivalence. The primary source of information is a bilingual corpus with 5 cases (50\%) of synonyms detected. Table 2 lists some examples.

\section{TABLE 2}

Students translation group

\begin{tabular}{|c|c|c|c|c|c|c|}
\hline 239 & alumnado & $\begin{array}{l}\text { студенческий } \\
\text { контингент }\end{array}$ & JCU_biling & $\begin{array}{l}\text { Traducción } \\
\text { descriptiva }\end{array}$ & Corpus & $\begin{array}{l}\text { (1) alumnado } \\
\text { universitario, colectivo } \\
\text { de estudiantes } \\
\text { universitarios, colectivo } \\
\text { de estudiantes } \\
\text { (2) -, Particularidad: (1) }\end{array}$ \\
\hline 237 & alumno & студент & JCU_biling & Calco & Corpus & $\begin{array}{l}\text { (1) alumno universitario } \\
\text { (2) - , Particularidad: (1) }\end{array}$ \\
\hline 369 & becario & стипендиат & ETU_es/ETU_ru & Calco & Corpus & \\
\hline
\end{tabular}

As identified in this section, a series of common data provides information related to university students and supporting documentation, some social and economic realities of their life.

\subsection{Examinations, certificates and diplomas}

The second group, regarding Examinations, certificates and diplomas, includes 59 bilingual translation units resorting to calque again in 29 cases $(49 \%)$. The bilingual origin of information has diminished: only 16 records $(27 \%)$ come from the legal bilingual corpus. Adding the synonyms ( 16 items, $27 \%$ ) and abbreviations ( 8 items, $14 \%$ ) to the data exploration bring the synonymy to the most frequently used means of the group. 


\section{TABLE 3}

Examinations, certificates and diplomas translation group

\begin{tabular}{lllllll}
\hline 32 & acreditación & аккредитация & $\begin{array}{l}\text { JCU_ } \\
\text { biling }\end{array}$ & Transliteración & Corpus & $\begin{array}{l}\text { (1) acreditación de } \\
\text { las competencias, } \\
\text { acreditación de } \\
\text { los títulos } \\
\text { (2) - Particularidad: (1) }\end{array}$ \\
\hline $\mathbf{3 4 7}$ & $\begin{array}{l}\text { arquitecto } \\
\text { técnico }\end{array}$ & $\begin{array}{l}\text { архитектор- } \\
\text { техник }\end{array}$ & AAG_es & Transliteración & Propia & \\
\hline $\mathbf{7 2 4}$ & $\begin{array}{l}\text { candidato } \\
\text { a doctor en } \\
\text { ciencias }\end{array}$ & кандидат наук & AAG_ru & $\begin{array}{l}\text { Traducción } \\
\text { aproximativa }\end{array}$ & Diccionario & \\
\hline
\end{tabular}

From Table 3, we observed that, as the research moves forward, certain cultural reality inequalities for Spain and Russia arise. For example, due to the current structure of higher education in the Russian Federation, there is still present an academic grade of a PhD candidate, which is currently nonexistent in Spain after the Bologna reforms.

\subsection{Institutions and educational facilities}

The third group of analysis, labelled as Institutions and educational facilities, identifies university infrastructure linking it to the training process on the university campus. Hence, the total number of 5 translation units (16\%) out of 32 items comes from the bilingual corpus; synonyms and abbreviations are limited to 9 records $(28 \%)$ and 3 records $(9 \%)$, respectively.

\section{TABLE 4}

Institutions and educational facilities translation group

\begin{tabular}{|c|c|c|c|c|c|c|}
\hline 345 & área & область & $\begin{array}{l}\text { AAG_es/ } \\
\text { AAG_ru }\end{array}$ & Calco & Corpus & $\begin{array}{l}\text { (1) área científica (2) - } \\
\text { Particularidad: (1) }\end{array}$ \\
\hline 381 & $\begin{array}{l}\text { campus de } \\
\text { excelencia } \\
\text { internacional }\end{array}$ & $\begin{array}{l}\text { кампус высшего } \\
\text { международного } \\
\text { стандарта }\end{array}$ & ETU_es & $\begin{array}{l}\text { Traducción } \\
\text { aproximativa }\end{array}$ & Propia & $\begin{array}{l}\text { (1) - (2) CEI - Campus } \\
\text { de Excelencia } \\
\text { Internacional } \\
\text { Particularidad: (2) }\end{array}$ \\
\hline 391 & $\begin{array}{l}\text { casa del } \\
\text { alumno }\end{array}$ & дом студента & ETU_es & Calco & Propia & \\
\hline
\end{tabular}

The data displayed in Table 4 above allows the advantage of getting closer to some Spanish contextual realities such as the International Campus of Excellence or Student's home, a specific building on campus where any university student has a place to study, eat or spend a meaningful leisure time. 


\subsection{Legislation}

The fourth translation group, Legislation, comprises 57 bilingual units mainly linked to the bilingual corpus (29 cases, 51\%). Calque equivalence technique is applied to translating 47 words or expressions (82\%), revealing little importance of synonymy (18 items, 32\%) and abbreviation (1 item, 2\%).

\section{TABLE 5}

Legislation translation group

\begin{tabular}{llllll}
\hline $\mathbf{3 1 0}$ & acuerdo & соглашение & JCU_biling & Calco & Corpus \\
\hline $\mathbf{3 3 7}$ & apartado & раздел & AAG_es/JCU_ru & Calco & Corpus \\
\hline $\mathbf{3 4 2}$ & aprobación & утверждение & AAG_es/ETU_ru & Calco & Corpus \\
\hline
\end{tabular}

National and international cooperation background continues making a strong contribution to the agreements signed, approved and authorised as Table 5 shows. This translation group seems to be the ideal showcase for cultural equivalence resulting from the common EHEA background. Certain differences were found in the political structures of Spain (parliamentary monarchy) and Russia (federal semiparliamentary republic). In fact, applied to university diplomas, Spanish ones are awarded on behalf of the King of Spain whilst Russian students get university diplomas without any signature of the Head of the State. Another example is the importance given in Spain to the Official State Bulletin or "Boletín Oficial del Estado". It is an official document widely accessible to ordinary citizens; meanwhile, in the Russian Federation, there is no similar connection.

\subsection{Advisory bodies}

The fifth group called Advisory bodies contains an overall quantity of 95 translation units, 43 records (45\%) coming from our bilingual corpus. With a predominance of calque equivalence (62 items, $65 \%$ ), it is also worth stressing that the number of synonyms and abbreviations in this group has reached 28 items (29\%) and 33 items (35\%), respectively.

\section{TABLE 6}

Advisory bodies translation group

\begin{tabular}{|c|c|c|c|c|c|c|}
\hline 31 & agencia & структура & $\begin{array}{l}\text { JCU_- } \\
\text { biling }\end{array}$ & Calco & Corpus & $\begin{array}{l}\text { (1) агентство, (2) - } \\
\text { Particularidad: (1) }\end{array}$ \\
\hline 321 & $\begin{array}{l}\text { Agencia Andaluza } \\
\text { de Evaluación } \\
\text { (AGAE) }\end{array}$ & $\begin{array}{l}\text { Андалусское } \\
\text { агентство оценки } \\
\text { качества }\end{array}$ & AAG_es & Calco & Propia & $\begin{array}{l}\text { (1) - , (2) AGAE - Agencia } \\
\text { Andaluza de Evaluación } \\
\text { Particularidad: (2) }\end{array}$ \\
\hline 322 & agencia ejecutiva & $\begin{array}{l}\text { исполнитель- } \\
\text { ное агентство }\end{array}$ & ETU_es & Calco & Propia & \\
\hline
\end{tabular}


As Table 6 shows, there are many similar national concepts and institutions in both countries; unless otherwise decided, the EHEA quality assurance could help Russian tertiary system move towards modernisation.

\subsection{Managing staff}

The sixth group, Managing staff translation group, represents staff members carrying out administrative and organisational work. The total quantity of 24 bilingual translation units collected here includes only 6 records (25\%) extracted from the bilingual corpus. With the number of equivalent items achieving 10 cases (42\%), calque is the most widely used resource. Meanwhile, there are 5 synonymous items (21\%) and 2 abbreviations (8\%).

\section{TABLE 7}

Managing staff translation group

\begin{tabular}{lllllll}
\hline $\mathbf{4 2 1}$ & comisario & $\begin{array}{l}\text { уполномо- } \\
\text { ченный }\end{array}$ & ETU_es/JCU_ru & $\begin{array}{l}\text { Traducción } \\
\text { aproximativa }\end{array}$ & $\begin{array}{c}\text { Corpus } \\
\text { (1) представитель, (2) } \\
\text {-, Particularidad: (1) }\end{array}$ \\
\hline $\mathbf{4 5 5}$ & coordinador & координа-тор & AAG_es/JCU_ru & Transliteración & Corpus & \\
\hline $\mathbf{4 6 8}$ & decano & декан & ETU_es & Transliteración & Corpus & $\begin{array}{l}\text { (1) director de } \\
\text { departamento, (2) - , } \\
\text { Particularidad: (1) }\end{array}$ \\
\hline
\end{tabular}

Three examples are given in Table 7 in order to illustrate a number of positions, some of them are non-remunerated ones, that cover a wide spectrum of administrative university work. Another noteworthy fact of a gender equivalence matter is the evolution of Spanish managing positions from only male gender into female names including among others "director-directora", "rector-rectora", "supervisor-supervisora".

\subsection{Training processes and resources}

The seventh group, Training processes and resources translation group, related to a set of 232 bilingual translation units ranging from academic aspects to financial or material resources. Calque technique (155 items, 67\%) turns again into the main approach towards equivalence. Addressing the issue of synonymy and abbreviations, there are 67 records (29\%) and 6 records (3\%), respectively.

Table 8 provides selected examples of equivalent terms of cultural and social realities existing in both countries except for such factors as examination types, marks or access to higher education. There still remains a significant tradition rooted in the Soviet Union and the Tsarist Empire that preserves differences even during the Bologna Reform. Russian marks record shows numbers and words from 5 "отлично" (the highest mark) to I “неудовлетворительно" (fail). Taking this difference as an example, we understand the necessity of formal analysis of higher education in both countries for improving qualifications transfer. 


\section{TABLE 8}

Training processes and resources translation group

\begin{tabular}{|c|c|c|c|c|c|c|}
\hline 340 & apoyo & поддержка & AAG_es/AAG_ru & Calco & Corpus & \\
\hline 109 & aprendizaje & обучение & JCU_biling & Calco & Corpus & \\
\hline 220 & $\begin{array}{l}\text { aprendizaje } \\
\text { a lo largo } \\
\text { de la vida }\end{array}$ & $\begin{array}{l}\text { обучение } \\
\text { в течение } \\
\text { всей жизни }\end{array}$ & JCU_biling & Calco & Corpus & $\begin{array}{l}\text { (1) aprendizaje permanente, } \\
\text { aprendizaje a lo largo de la } \\
\text { vida, (2) - , Particularidad: (1) }\end{array}$ \\
\hline
\end{tabular}

\subsection{Teaching staff}

The eighth group, Teaching staff translation group, embraces different faculty members of both Spanish and Russian universities and has 12 bilingual records. It includes 10 pairs (83\%) gathered from our corpus, 6 synonymous items (50\%), and abbreviations represent only a case (8\%). In terms of equivalence, the current group makes use of approximate translation in 7 cases (58\%).

\section{TABLE 9}

Teaching staff translation group

\begin{tabular}{|c|c|c|c|c|c|c|}
\hline 609 & catedrático & профессор & $\begin{array}{l}\text { AAG_es/ } \\
\text { ETU_ru }\end{array}$ & $\begin{array}{l}\text { Traducción } \\
\text { aproximativa }\end{array}$ & Corpus & \\
\hline 313 & $\begin{array}{l}\text { cuerpo } \\
\text { docente }\end{array}$ & $\begin{array}{l}\text { профессорско - } \\
\text { преподава-тель- } \\
\text { ский состав }\end{array}$ & $\begin{array}{l}\text { ETU_es/ } \\
\text { ETU_ru }\end{array}$ & $\begin{array}{l}\text { Traducción } \\
\text { descriptiva }\end{array}$ & Corpus & $\begin{array}{l}\text { (1) cuerpo de } \\
\text { profesores, cuerpo de } \\
\text { funcionarios docentes, } \\
\text { docente universitario, } \\
\text { сuerpo académico; } \\
\text { преподавательский } \\
\text { состав } \\
\text { (2) -, Particularidad: (1) }\end{array}$ \\
\hline 509 & docente & преподава-тель & $\begin{array}{l}\text { AAG_es/ } \\
\text { AAG_ru }\end{array}$ & Calco & Corpus & $\begin{array}{l}\text { (1) formador, profesional } \\
\text { de la educación; доцент } \\
\text { (2) -, Particularidad: (1) }\end{array}$ \\
\hline
\end{tabular}

As Table 9 shows, records 609 "full professorship" versus 731 "associate professor", specialised translation also recognised labour conditions and progress of younger staff members towards higher responsibility and more stable civil service. Some of the university professors are civil servants occupying positions of tenure track professionals as well as, academically speaking, hold masters and doctoral degrees in science, technology and humanities. Others are still preparing for this mission, while accumulating more teaching and research experience in a variety of educational responsibilities. 


\subsection{Systems and levels of education}

The next, ninth group, deals with Systems and levels of education in charge of gathering data on tertiary training structures previous to Bologna Process. We pay special attention to the common denominators of educational cycles and provide a range of examples including 64 bilingual records. Within this category, there are 42 items (66\%) translated using calque equivalence technique together with 27 synonyms (89\%) and only one case of abbreviation (2\%).

\section{TABLE 10}

Systems and levels of education translations group

\begin{tabular}{|c|c|c|c|c|c|c|}
\hline 452 & conversión & переход & $\begin{array}{l}\text { AAG_es/ } \\
\text { AAG_ru }\end{array}$ & Calco & Corpus & \\
\hline 287 & $\begin{array}{l}\text { diplomatura } \\
\text { (pregrado) }\end{array}$ & $\begin{array}{l}\text { предвыпуск-ной } \\
\text { (квали-фикацион- } \\
\text { ный) цикл }\end{array}$ & $\begin{array}{l}\text { JCU_- } \\
\text { biling }\end{array}$ & $\begin{array}{l}\text { Traducción } \\
\text { descriptiva }\end{array}$ & Corpus & \\
\hline 131 & doctorado & аспирантура & $\begin{array}{l}\text { JCU_ } \\
\text { biling }\end{array}$ & $\begin{array}{l}\text { Traducción } \\
\text { aproximativa }\end{array}$ & Corpus & $\begin{array}{l}\text { (1) posgrado, formación } \\
\text { de doctorado, } \\
\text { formación doctoral; } \\
\text { подготовка док-торов } \\
\text { наук, докторская степень, } \\
\text { докторский уровень } \\
\text { (2) - , Particularidad: (1) }\end{array}$ \\
\hline
\end{tabular}

In Table 10, we can see three examples of specialised translations combining a mix of the European Higher Education Area's notions varying from general concepts like 452 "conversion" to more specific ones such as 131 "doctoral studies" or 287 "bachelor degree".

\subsection{Society}

For the next translation group, Society, 115 bilingual records related to modern society were selected. International and national communities generated numerous changes in the tertiary education regulatory framework and the calque technique used in 78 translation pairs $(68 \%)$ is a good proof of it. Besides, the group comprises 18 synonymous records ( $16 \%$ ) as well as four abbreviations (3\%).

According to Table 11, a few samples shown support the general context of the translation group, determining a strong connection between the academic environment and social background. The current set of bilingual items recovered from the specialised corpus is also fitted with some contemporary issues such as managerial autonomy or reliable social issues among others. 


\title{
TABLE 11
}

Society translations group

\begin{tabular}{lllllll}
\hline $\mathbf{2 5 7}$ & $\begin{array}{l}\text { accesibilidad } \\
\text { internacional }\end{array}$ & $\begin{array}{l}\text { международная } \\
\text { открытость }\end{array}$ & JCU_biling & Calco & Corpus & \\
\hline $\mathbf{1 4}$ & agente social & социальный партнер & JCU_biling & Calco & Corpus & \\
\hline $\mathbf{1 7 4}$ & $\begin{array}{l}\text { autonomía } \\
\text { universitaria }\end{array}$ & $\begin{array}{l}\text { университетская } \\
\text { автономия }\end{array}$ & JCU_biling & Calco & Corpus & (1) autonomía de \\
& & & & & $\begin{array}{l}\text { las universidades } \\
\text { (2) - , Particularidad: (I) }\end{array}$ \\
\hline
\end{tabular}

\section{Results}

A translation perspective applied to the study of the EHEA context made it possible to obtain some quantitative data on translation techniques in each of the translation groups suggested. Moreover, the information analyses provided above guide us towards the outcomes' presentation. Figure 2 shows correspondences that may be of interest for the contrastive analysis procedure.

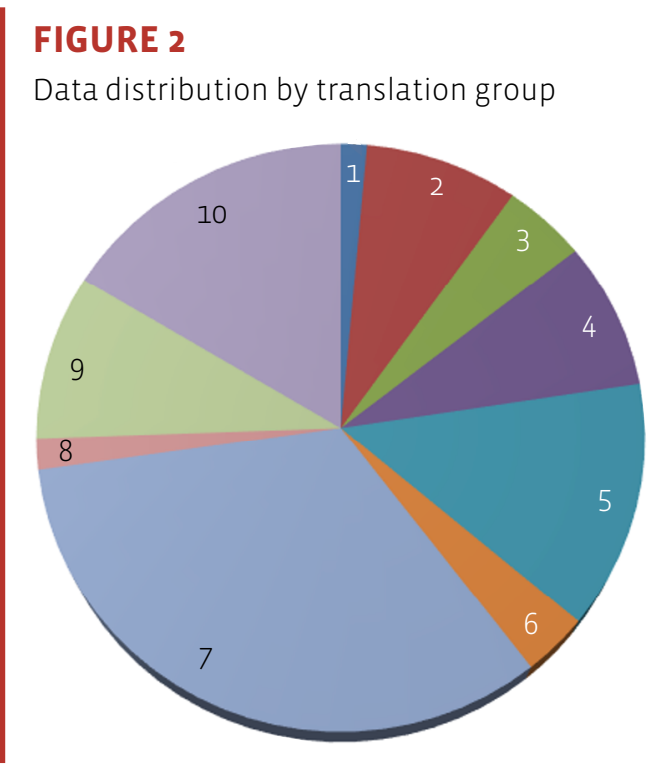

\author{
1. Students $1 \%$ \\ 2. Examinations, certificates and diplomas $9 \%$ \\ 3. Institutions and educational facilities $5 \%$ \\ 4. Legislation $8 \%$ \\ 5. Advisory bodies 14\% \\ 6. Managing staff $3 \%$ \\ 7. Training processes and resources $33 \%$ \\ 8. Teaching staff $2 \%$ \\ 9. Systems and levels of education $9 \%$ \\ 10. Society $16 \%$
}

More specifically, the distribution of considered bilingual translation pairs tends to differ very much from groups 7 (33\%), 10 (16\%) and 5 (14\%) to groups $6(3 \%), 8(2 \%)$ and 1 ( $1 \%)$. According to the given results, the documentation included in the corpus emphasises the importance of training processes and resources, social basis and advisory bodies. The impact of the three areas named established an active connection to the course of implementation of the European Higher Education Area in the languages studied. Notwithstanding the difficulties 
related to the common base of managing and teaching staff, along with students, the necessary educational model starts to appear on the horizon.

Regarding the linguistic corpus focus as a part of the mixed approach, its initial aim was not only optimising documentary base but linking monolingual corpus (410 resulting translation pairs, 59\%) research to the bilingual one (290 resulting translation pairs, 41\%).

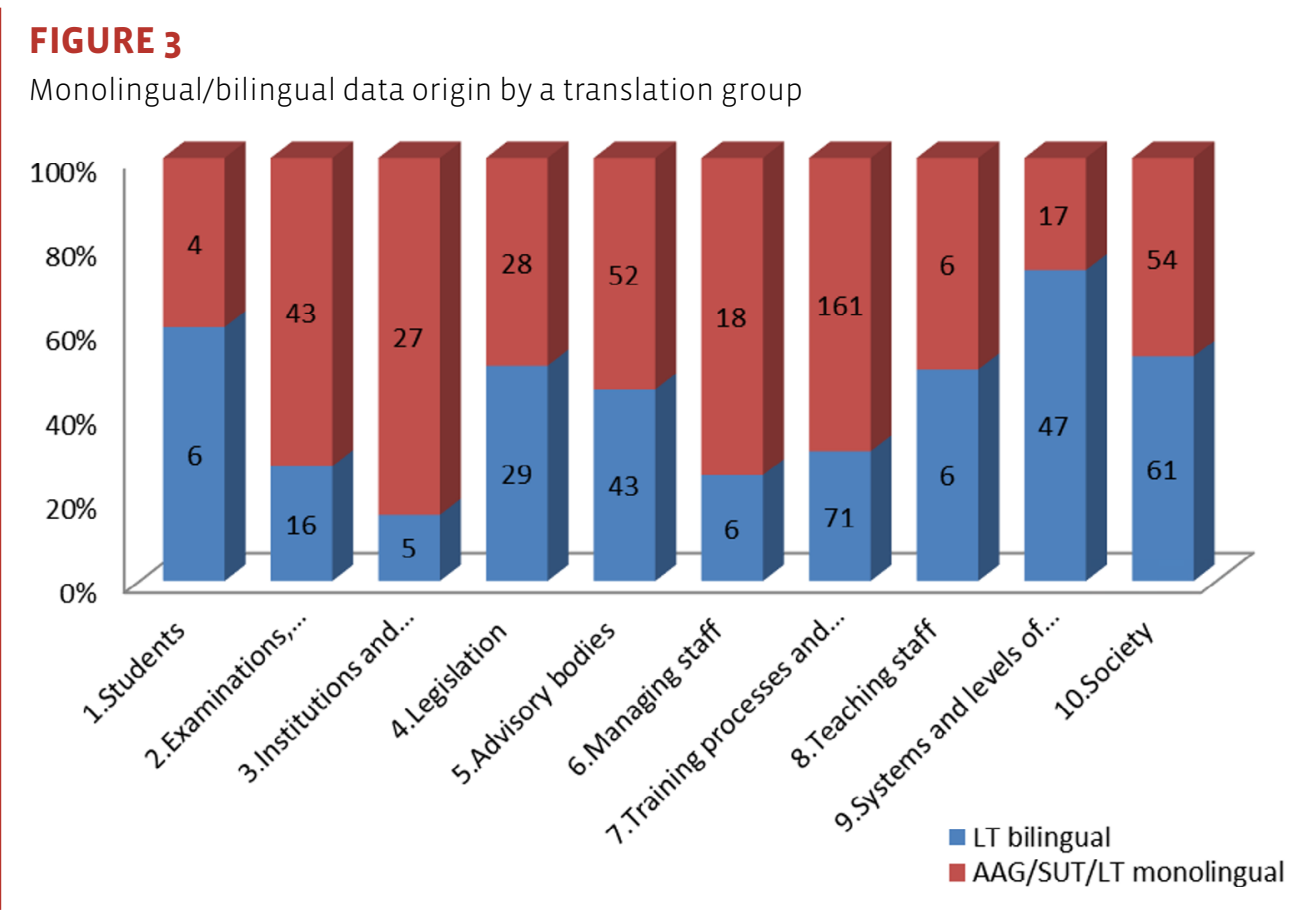

However, as shown in Figure 3, while some groups display a specific predominance of the parallel bilingual legal text corpus (LT) marked in blue, others tend to associate background data with monolingual academic and administrative general corpus (AAG), specialised university texts corpus (SUT) and legal texts corpus (LT).

Figure 3 depicts four main translation groups of Systems and levels of education (73\%), Students (60\%), Society (53\%) and Legislation (51\%) that exceed $50 \%$ of the parallel translations border. These data highlight a positive trend towards supporting the similarity of university realities of the Bologna reform in Spain and Russia. A strong impulse provided by the new tertiary model pushes us to innovate the whole society and the university system as an integral part of it.

The next step towards the key point of the research of the translation equivalence concerns the most frequently used technique (calque, transliteration, descriptive translation, approximate translation). The information detailed in Table 12 reports numerical data relevant for each equivalence technique within every translation group. 


\section{TABLE 12}

Translation equivalence by translation group

\begin{tabular}{|c|c|c|c|c|c|}
\hline TRANSLATION GROUP & CALQUE & $\begin{array}{l}\text { TRANS- } \\
\text { LITERATION }\end{array}$ & $\begin{array}{l}\text { DESCRIPTIVE } \\
\text { TRANSLATION }\end{array}$ & $\begin{array}{l}\text { APPROXIMATE } \\
\text { TRANSLATION }\end{array}$ & $\begin{array}{l}\text { TOTAL AMOUNT } \\
\text { OF BILINGUAL } \\
\text { RECORDS }\end{array}$ \\
\hline 1.Students & 8 & 1 & 1 & 0 & 10 \\
\hline $\begin{array}{l}\text { 2.Examinations, } \\
\text { certificates and diplomas }\end{array}$ & 29 & 11 & 3 & 16 & 59 \\
\hline $\begin{array}{l}\text { 3. Institutions and } \\
\text { educational facilities }\end{array}$ & 16 & 12 & 0 & 4 & 32 \\
\hline 4. Legislation & 47 & 7 & 0 & 3 & 57 \\
\hline 5. Advisory bodies & 62 & 11 & 5 & 17 & 95 \\
\hline 6. Managing staff & 10 & 8 & 0 & 6 & 24 \\
\hline $\begin{array}{l}\text { 7. Training processes } \\
\text { and resources }\end{array}$ & 155 & 51 & 8 & 18 & 232 \\
\hline 8. Teaching staff & 4 & 0 & 1 & 7 & 12 \\
\hline $\begin{array}{l}\text { 9. Systems and levels } \\
\text { of education }\end{array}$ & 42 & 5 & 8 & 9 & 64 \\
\hline 10. Society & 78 & 24 & 4 & 9 & 115 \\
\hline TOTAL AMOUNT & 451 & 130 & 30 & 89 & 700 \\
\hline
\end{tabular}

On top of the list we can see the calque technique as its values are higher than the rest of the translation techniques: 451 bilingual records (64\%). This may entail a relative correspondence of academic sectors of both countries analysed. Meanwhile, the transliteration (130 pair items, 19\%) and approximate translation techniques (89 pair items, 13\%) offer a valid resource for aligning higher education terminology. Moreover, the approximate translation results recall inexistent realities for Spanish or Russian systems. The least frequent technique, the descriptive translation (30 records, 4\%), is characterised by an excessive length looking not quite appropriate for the limited space given for introducing translations.

Thus, the presence of the equivalence recalled, we focus on the typology of translations made with the help of the linguistic corpus, bilingual and monolingual dictionaries and some translations provided by the researchers. For the study based on the original documentation processed through the corpus, the latter approach is connected with the majority of cases settled, as Table 13 shows.

Out of the 700 bilingual records, 569 translations (81\%) were agreed upon linguistic corpus versus less frequent help of dictionaries (72 pair items, 10\%) or personal suggestions (59 pair 


\section{TABLE 13}

Translation solutions applied

\begin{tabular}{|c|c|c|c|c|}
\hline TRANSLATION GROUP & CORPUS & DICTIONARY & $\begin{array}{l}\text { TRANSLATION } \\
\text { SUGGESTED }\end{array}$ & $\begin{array}{l}\text { TOTAL AMOUNT OF } \\
\text { BILINGUAL RECORDS }\end{array}$ \\
\hline 1.Students & 9 & 1 & 0 & 10 \\
\hline $\begin{array}{l}\text { 2.Examinations, certificates } \\
\text { and diplomas }\end{array}$ & 43 & 7 & 9 & 59 \\
\hline $\begin{array}{l}\text { 3. Institutions and } \\
\text { educational facilities }\end{array}$ & 23 & 3 & 6 & 32 \\
\hline 4. Legislation & 49 & 4 & 4 & 57 \\
\hline 5. Advisory bodies & 65 & 8 & 22 & 95 \\
\hline 6. Managing staff & 19 & 4 & 1 & 24 \\
\hline $\begin{array}{l}\text { 7. Training processes } \\
\text { and resources }\end{array}$ & 195 & 30 & 7 & 232 \\
\hline 8. Teaching staff & 10 & 1 & 1 & 12 \\
\hline 9. Systems and levels of education & 57 & 1 & 6 & 64 \\
\hline 10. Society & 99 & 13 & 3 & 115 \\
\hline TOTAL AMOUNT & 569 & 72 & 59 & 700 \\
\hline
\end{tabular}

items, $9 \%)$. Even if some of the corpus solutions by translation group are slightly under the total number, such as group 2 (43 records, 73\%), 3 (23 records, $72 \%$ ), 5 (65 records, $68 \%$ ) or 6 (19 records, $79 \%$ ), they still contain substantial quantities of corpus elements. Whereby, they incorporate necessary data for identifying common EHEA ground represented in Spanish and Russian as well as a need to improve some parts of national university features.

This information gives a global perspective on the empirical validity of a specialised corpus in the translation environment. Nonetheless, it is also appropriate to keep a register of some other details that might be worth mentioning. For example, regarding the synonymy and abbreviation, there are several cases detected in every translation group analysed (see Figure 4 below).

Since these are singularities of the translations studied, listing 280 bilingual records, count on support of 199 synonyms occupying the first place, followed by 59 abbreviations and 22 mixed cases where both synonyms and abbreviations are found. To illustrate a mixed case, we have selected the pair Spanish-Russian "institución de educación superior - высшее учебное заведение" corresponding to the higher education institution. For the Spanish expression, there is a synonym "institución de enseñanza superior" and the abbreviation "IES" shortens the initial expression. Russian vocabulary offers a wider range of synonyms: "учреждение высшего образования", "институт высшего образования" as well as an abbreviation of "вуз". 


\section{FIGURE 4}

Synonyms and abbreviations distributed by the group

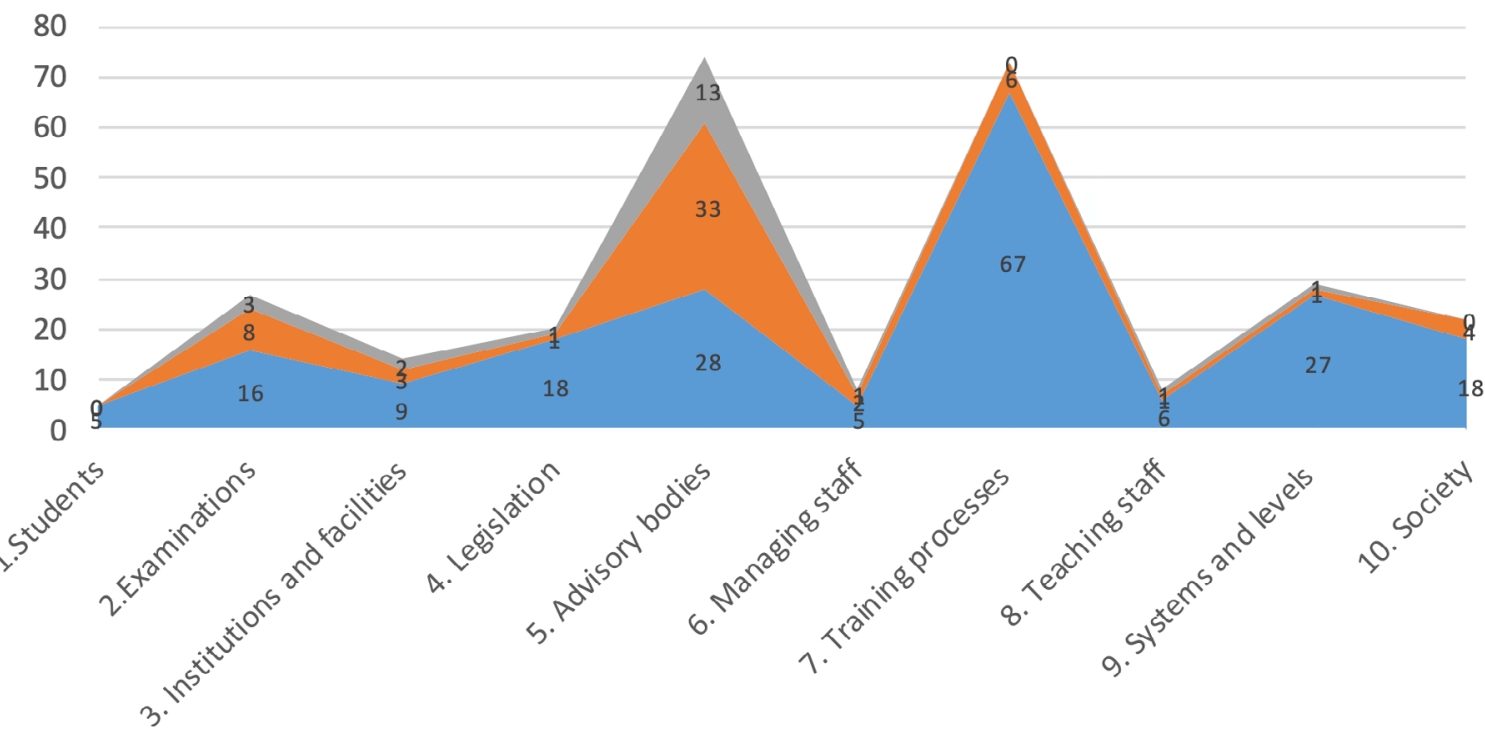

- Synonyms Abbreviations Synonyms \& abbreviations

It is in this regard that translation groups Training processes and resources (67 items, 34\%), Advisory bodies (28 items, 14\%) and Systems and levels of education ( 27 items, 14\%) become relevant for the general advance of the reforms due to the synonymous expressions related. Changes and different practical arrangements are still modifying specialised vocabulary of the academic domain, as demonstrated by the synonyms.

Looking at the quantity of abbreviation data compiled in Figure 4, we may also visually perceive predominance of Advisory bodies (33 items, 56\%), Examinations, certificates and diplomas (8 items, 14\%) or Training processes and resources (6 items, 10\%) groups. The synonyms and abbreviations combined in a record are located mainly in the Advisory bodies group (13 items, 59\%). The supremacy of the translation group 5 implies a certain degree of formal institutional participation in the reform, therefore underlining its political support and increased European cooperation.

Concluding with a summary of the most important outcomes of the research, translation groups have been constituted around a selected number of higher education themes. Moreover, to fill in the sets mentioned above, a long list of bilingual records was extracted out of the specialised corpus. The translation units collected were scrutinised and some interesting facts concerning equivalence and other particularities were obtained, allowing the presentation of these data through a bilingual glossary (shown in Figures 5 and 6). 


\section{FIGURE 5}

Bilingual Spanish-Russian glossary (simple version)

abono $\rightarrow$ оплата

academia $\rightarrow$ академия

accesibilidad internacional $\rightarrow$ международная

открытость

Agència per a la Qualitat del Sistema Universitari de Catalunya (AQU) $\rightarrow$ Агентство оценки качества в сфере высшего образования Каталонии

acceso $\rightarrow$ доступ

agenda $\rightarrow$ повестка дня

acción $\rightarrow$ действие

Agenda Europea de Modernización de las Universidades (AEMU) $\rightarrow$ Европейская программа модернизации университетов

\section{FIGURE 6}

Bilingual Spanish-Russian glossary (full version)

abono $\rightarrow$ оплата

CDT_E: Los interesados, a partir de 15 dias hábiles desde que presenten en la Oficina del Estudiante, la solicitud y justificante de abono de la tasa correspondiente, pueden retirar el correspondiente certificado académico

стт_RU: 26) принимает положения о системе оплаты труда и материального стимулирования работников вУза

DOM: Proceso y recursos formativos

academia $\rightarrow$ академия

CTX_Es: Universidad, academia, instituto

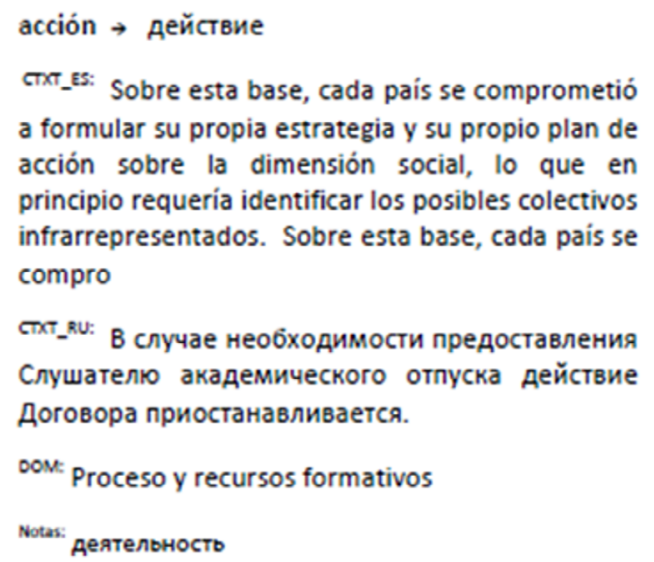
a formular su propia estrategia y su propio plan de acción sobre la dimensión social, lo que en principio requería identificar los posibles colectivos infrarrepresentados. Sobre esta base, cada pais se compro

станди: В случае необходимости предоставления Слушателю академического отпуска действие Договора приостанавливается.

DOM: Proceso y recursos formativos

Notas: деятельность

\section{Conclusions}

The overall results of the study show the theoretical and practical contribution to the linguistic method of corpus research as well as to terminology, translation and bilingual lexicology. In conclusion, once the research on the combined approaches to the study of the EHEA translations was completed, several research objectives proposed in the introduction of the original project were achieved:

- Documentation typology of university context applied to Spanish and Russian Ianguages was detected and a common classification was included in the corpus design.

- Bilingual translation database was generated, it helped systematise and detect equivalence in the specialised context. We were able to observe the quantitative variation which depended on the translation group in the analytical section. 
- The study of Spanish and Russian higher education lexis has been undertaken from the perspective of combined approaches to terminology and translation with the use of a linguistic corpus.

- A bilingual Spanish-Russian glossary of 700 specialised translation units was compiled.

In summary, translation data sorted by database fields of equivalence, synonyms and abbreviations were exploited both for analysis and classification tasks. The information obtained for professional and personal use includes the Spanish/Russian translation unit, contextual information and usage examples, synonyms and abbreviations. Therefore, it includes helpful data for a professional translator, sociocultural mediator or an incoming student into the higher education system in Spain or in Russia. Thus, the work, aimed at providing a conceptual analysis on translations, could be the first stage towards further harmonisation of current conceptual background in such diverse lands as the countries mentioned.

\section{References}

Alcaraz Varó, Enrique, and Brian Hughes, 2002: El español jurídico, Barcelona: Editorial Ariel.

Alcaraz Varó, Enrique, and María Antonia Martínez Linares, 1997: Diccionario de lingüística moderna, Barcelona: Editorial Ariel.

Aznar Royo, José Ignacio, and Tania Alarcon Rodriguez, 2006: Etimologías Grecolatinas, México: Pearson Educación.

BAKER, Mona, 1992: In Other Words: A Coursebook on Translation, London: Routledge.

Bergenholtz, Henning, and Sven TARP, 2010: "LSP Lexicography or Terminography? The lexicographer's point of view" in Pedro Antonio Fuertes-Olivera (ed.): Specialised Dictionaries for Learners, Berlin / New York: De Gruyter, 27-37.

Berlin Communique, 2003: Conference of Ministers responsible for Higher Education in Berlin on 19 September 2003 [http://www.ehea.info/Uploads/about/Berlin_Communique1.pdf, accessed 10th May 2018].

BhatıA, Vijay, 1993: Analysing genre: language use in professional settings, London: Longman.

Bologna Declaration, 1999: Ministerial Conferences on Bologna Process - European Higher Education Area. The Bologna Declaration of 19 June 1999 [http://www.ehea.info/Uploads/Declarations/BOLOGNA_DECLARATION1.pdf, accessed 5th March 2018]. 
Cabré, Maria Teresa, 1993: La Terminología. Teoría, métodos, aplicaciones, Barcelona: Editorial Antártida.

Calvo Rigual, Cesáreo, and Maria Vittoria Calvı, 2014: "Translation and Lexicography: A Necessary Dialogue", MonTI 6, 37-62.

CRYSTAL, David, 2008: A dictionary of linguistics and phonetics, Oxford: Blackwell Publishing.

Faber, Pamela, Silvia Montero Martínez, María Rosa Castro Prieto, José Senso Ruiz, Juan Antonio Prieto Velasco, Pilar león Araúz, Carlos Márquez Linares and Miguel Vega Expósito, 2006: "Process-oriented terminology management in the domain of Coastal Engineering", Terminol$\operatorname{ogy} 12(2), 189-213$.

Faber Benitez, Pamela, Pilar León Araúz, 2010: "Dinamismo conceptual en las bases de conocimiento terminológico: el caso de EcoLexicon”, Ikala 15 (25), 75-100.

García Yebra, Valentín, 1989: Teoría y práctica de la traducción, Madrid: Editorial Gredos.

Gaudin, François, 1993: Socioterminologie: des problèmes sémantiques aux pratiques institutionnelles, Rouen: Publications de l'Université de Rouen.

Hannay, Mike, 2003: "Types of bilingual dictionaries" in Piet van Sterkenburg (ed.): A Practical Guide to Lexicography, Amsterdam/Philadelphia: John Benjamins, 145-153.

Hualde, José Ignacio, Antxon Olarrea, Anna María Escobar and Catherine Travis, 2010: Introducción a la lingüística hispánica, New York: Cambridge University Press.

Hurtado AlBiR, Amparo, 2011: Traducción y traductología: introducción a la traductología, Madrid: Ediciones Cátedra.

Jakobson, Roman, 1959: "On Linguistic Aspects of Translation” in Reuben Brower (ed.): On Translation. Harvard Studies in Comparative Literature, Cambridge, Mass: Harvard University Press, 232-239.

Jiménez-CRespo, Miguel, 2009: “El uso de corpus textuales en localización”, Revista Tradumatica 2, 1-15 [http://www.raco.cat/index.php/Tradumatica/article/viewFile/154832/206726, accessed 2nd February, 2018].

LeRAT, Pierre, 1997: Las lenguas especializadas, Barcelona: Ariel.

McEnery, Tony, and Andrew Hardie, 2012: Corpus Linguistics: Method, Theory and Practice, Cambridge: Cambridge University Press. 
Newmark, Peter, 1988: A Textbook of Translation, Hertfordshire: Prentice Hall International.

NIDA, Eugene, 1964. Towards a science of translation, with special reference to principles and procedures involved in Bible translating, Leiden: Brill.

NIDA, Eugene, and Charles TABER, 1982: The Theory and Practice of Translation, Leiden: Brill.

O'KeefFe, Anne, and Michael McCARTHY, 2010: "Historical perspective: what are corpora and how have they evolved?" in Anne O'KeEFFE and Michael McCarTHY (eds.): The Routledge Handbook of Corpus Linguistics, New York: Routledge, 3-13.

Panou, Despoina, 2013: "Equivalence in Translation Theories: A Critical Evaluation", Theory and Practice in Language Studies 3 (1), 1-6.

Pérez Hernández, M. Chantal, 2002: Explotación de los corpora textuales informatizados para la creación de bases de datos terminológicas basadas en el conocimiento. Tesis doctoral, Universidad de Málaga.

Polyakova, Oksana, and Miguel Ángel Candel-Mora, 2016: "Clasificación textual del lenguaje profesional y académico en la universidad: una propuesta orientada a la convergencia europea", E-Aesla 2, 393-404.

SAger, Juan Carlos, 1993: Curso práctico sobre el procesamiento de la terminología, Madrid: Fundación Germán Sánchez Ruipérez/Pirámide.

Sager, Juan Carlos, David Dungworth and Peter F. McDonald, 1980: English Special Languages: Principles and Practice In Science and Technology, Wiesbaden: Brandstetter.

Sanz Álava, Inmaculada, 2007: El Español Profesional y Académico en el aula universitaria, Valencia: Tirant lo blanch.

Sorbonne Joint Declaration, 1998: Joint declaration on harmonisation on the architecture of the European higher education system [http://www.ehea.info/Uploads/Declarations/SORBONNE_DECLARATION1.pdf, accessed 10th May 2018].

Swales, John, 1990: Genre Analysis - English in Academic and Research Settings, Cambridge: Cambridge University Press.

Swales, John, 2004: Research Genres: Explorations and Applications, Cambridge: Cambridge University Press.

TARP, Sven, 2009: “Reflections on Lexicographic User Research”, Lexikos 19, 275-296. 
Temmerman, Rita, 1997: "Questioning the Univocity Ideal. The difference between socio-cognitive Terminology and traditional Terminology”, Hermes 18, 51-90.

Varela Fernandez, Hellen, 2002: La traducción del lenguaje académico-administrativo, especializado y jurídico dentro del ambiente universitario: el caso de la Universidad Nacional (Costa Rica). Tesis de maestría, Universidad Nacional de Costa Rica.

VARgas SierRa, Chelo, 2005: Aproximación terminográfica al lenguaje de la piedra natural: propuesta de sistematización para la elaboración de un diccionario traductológico. Tesis doctoral, Universidad de Alicante.

VARgas Sierra, Chelo, 2006: "Diseño de un corpus especializado con fines terminográficos: el corpus de la piedra natural”, Debate terminológico 2 (7), 84-107.

Verba, Galyna, and Rafael Guzmán Tirado, 2005: Curso de traducción jurídico-administrativa (ruso/español y español/ruso), Madrid: Centro de Lingüística Aplicada ATENEA.

Villayandre Llamazares, Milka, 2010: Aproximación a la lingüística computacional. Tesis doctoral. Universidad de León.

Vinay, Jean-Paul, and Jean Darbelnet, 2000: "A Methodology for Translation" in Lawrence Venuti (ed.): The Translation Studies Reader, London: Routledge, 84-93.

Wüster, Eugen, 1967: The machine tool: an interlingual dictionary of basic concepts: comprising an alphabetical dictionary and a classified vocabulary with definitions and illustrations, London: Technical Press.

\subsection{Russian references}

Bahtın, Mihail Mihailovič, 1996: Problema rečevyh žanrov. Sobranie sočinenij. - Tom 5: Raboty 1940-1960 gg, Moskva: Russkie slovari.

LATY̌̌Ev, Lev Konstantinovič, i Arkadij Lvovič Semenov, 2003: Perevod: teoriâ, praktika i metodika prepodavaniâ, Moskva: Akademiâ. 